\title{
Apoptosis of HeLa Cells via Caspase-3 Expression Induced by Chitosan-Based Nanoparticles of Annona squamosa Leaf Extract: In vitro Study
}

\author{
Amaq Fadholly', Arif Nur Muhammad Ansori', Annise Proboningrat ${ }^{1}$, Alexander Patera Nugraha ${ }^{2}$, \\ Regina Purnama Dewi Iskandar², Fedik Abdul Rantam³, Sri Agus Sudjarwo4,*
}

${ }^{1}$ Doctoral Student of Veterinary Science, Faculty of Veterinary Medicine, Universitas Airlangga, INDONESIA ${ }^{2}$ Doctoral Student of Medical Science, Faculty of Medicine, Universitas Airlangga, INDONESIA.

${ }^{3}$ Department of Veterinary Microbiology, Faculty of Veterinary Medicine, Universitas Airlangga, INDONESIA.

${ }^{4}$ Department of Pharmacology, Faculty of Veterinary Medicine, Universitas Airlangga, INDONESIA.

\begin{abstract}
Background: Annona squamosa is reported has a significant cytotoxic activity in some cancer cells. Objectives: Thus, this study aim to investigate Annona squamosa leaf extract induced by chitosan nanoparticles (nano-ASLE) to enhance their biological activity as anticancer agent on HeLa cells. Methods: Nano-ASLE (50, 100, 200, $400 \mu \mathrm{g} / \mathrm{mL}$ in DMSO) given on HeLa cells to determined $I_{50}$ value by MTT assay. Then, it was devided into three groups as follow $\mathrm{IC}_{50}, 2 \mathrm{IC}_{50}, 4 \mathrm{IC}_{50}$ continued with analysis of caspase-3 expression. Results: The present study demonstrated that nano-ASLE can surpress HeLa cells proliferation with the $\mathrm{IC}_{50}$ value of $344.48 \mu \mathrm{g} / \mathrm{mL}$ and rapid enhancement of caspase- 3 activity has the mean score of 65.3 cell expression and the lowest score shows 45.3 cell expression. Conclusion: Nano-ASLE lead to HeLa cell death via the mitochondrial pathway on caspase- 3 expression. In addition, the further studies are needed to obtain the loading efficiency, release of drug concentration and in vivo study of nano-ASLE to suppress HeLa cells.

Key words: Annona squamosa, Cytotoxicity, Apoptosis, Caspase-3, Nanoparticles.
\end{abstract}

Key Messages: Apoptosis effect of Annona squamosa nanoparticles.

\section{INTRODUCTION}

Cancer has emerged as one of the strongest diseases which causes deaths since many years ago. ${ }^{1}$ The second most common gynecological tumors that caused mortality in women worldwide is cervical cancer. ${ }^{2}$ Many studies assess some botanical products as the chemopreventive agent and more than 5000 bioactive compounds have been identified and still continuously increasing for the new one. These novel phytomedicines have shown running as anticancer drug candidate in vitro models. ${ }^{3-5}$ Annona squamosa is called as Srikaya which belongs to Annonaceae family and considered as the medicinal plant for cardiac disease, diabetes and cancer. Bioactive compounds of the leaf extract presence flavonoids, alkaloids, saponins, glycosides, phenolic, tannins, terpenoids, steroids. ${ }^{6}$ Annona squamosa has been reported for the discovery of new compounds. Acetogenins have been isolated from the many plants of the Annonaceae. ${ }^{7}$ Acetogenins isolated from Annona squamosa is reported to has a significant cytotoxic activity against 9KB, A549, HT-29, 9ASK cancer cells and the caspase- 3 activation on HL-60 cells. ${ }^{8,9}$ Additionally, some studies showed that silver based Annona squamosa extract nanoparticle are reported to have the cytotoxic effect and apoptosis induction on MCF-7 cells. ${ }^{10}$

Nanotechnology is a promising approach to enhance the bioavailability of herbal medicine. Non-toxic biopolymer material
Submission Date: 25-09-2019; Revision Date: 26-12-2019; Accepted Date: 05-02-2020

DOI: 10.5530/ijper.54.2.47 Correspondence: Prof. Sri Agus Sudjarwo, Department of Pharmacology, Faculty of Veterinary Medicine, Universitas Airlangga, INDONESIA. Phone: +6285645000684 E-mail: ags158@yahoo.com

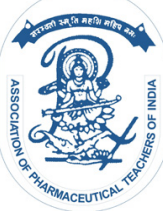

www.ijper.org 
is one of the nanoparticles colloidal which is expected to protect bioactive compound. A carrier material like the sodium tripolyphosphate (Na-TPP) and chitosan combination are used to preserve releasing of the core. Chitosan is a non-toxic material widely used as nanoparticle-forming polymer. ${ }^{11}$ Therefore, this study designed to prepare nano chitosan-Annona squamosa leaf extract to enhance their bioactivities as the anticancer agent on HeLa cells to evaluate the caspase expression as one of apoptosis marker of cells.

\section{MATERIALS AND METHODS}

\section{Ethical Approval}

All treatment procedures have been tested through Ethics Committee of Gadjah Mada University (KE/FK/0106/EC/2018).

\section{Preparation of Annona squamosa Leaf Extract}

The leaves were collected from Lumajang Regency, East Java, Indonesia. The leaves were cleaned and chopped into small pieces and shade dried. They were powdered using mechanical blender and passed through the coarse sieve $(0.2 \mathrm{~mm})$. The powder was macerated with ethanol $96 \%$ for $72 \mathrm{hr}$ at $37^{\circ} \mathrm{C}$. The extract was evaporated in the waterbath at the temperature of $60^{\circ} \mathrm{C}$. The residue was then stored in a refrigerator at the temperature of $0-4^{\circ} \mathrm{C}$.

\section{Preparation of Annona squamosa Extract Induced Chitosan}

Annona squamosa leaf extract induced with chitosan (nano-ASLE) were prepared in the method of ionic gelation with slight modification. Chitosan $(0.1 \% \mathrm{w} / \mathrm{v})$ was dissolved in acetic acid $(0.25 \% \mathrm{v} / \mathrm{v})$ and sodium tripolyphosphate $(0.84 \% \mathrm{w} / \mathrm{v})$. Annona squamosa leaf extract $(1 \mathrm{~g})$ was dissolved in $50 \mathrm{~mL}$ distilled water and added with $100 \mathrm{~mL}$ chitosan in acetic acid, followed by $350 \mathrm{~mL}$ sodium tripolyphosphate dripping in the solution stirring condition at the room temperature. It was stirred for $2 \mathrm{hr}$ and followed by centrifuge $30 \mathrm{~min}$ in $6000 \mathrm{rpm}$, then supernatant was collected then dried for cells treatment. ${ }^{12}$

\section{Electron Microscope Analysis}

Morphology of nano-ASLE was evaluated using Scanning Electron Microscope (SEM), $15 \mathrm{kV}$, model 54160, Hitachi, Japan.

\section{Particle Size Analysis}

particle size distribution of nano-ASLE was performed with dynamic light scattering (DLS) method using Zetasizer Nano ZS (Malvern Instrument Ltd., UK).

\section{HeLa Cells Culture}

HeLa cells were cultured in DMEM with 10\% (v/v) fetal bovine serum, 3\% streptomycin-penicillin and 1\% fungizone in $5 \% \mathrm{CO}_{2}$ incubator at $37^{\circ} \mathrm{C}$. Cells were maintained in $25 \mathrm{~cm}^{2}$ flask with $7 \mathrm{~mL}$ media then harvested using 0.25 trypsin-EDTA after reaching $80 \%$ on confluency.

\section{$\mathrm{IC}_{50}$ Value Determination}

The $\mathrm{IC}_{50}$ value of nano-ASLE was determined using MTT assay. HeLa cells were cultivated at a density of $1 \times 10^{4}$ cells/well in 96-well plates and incubated at $37^{\circ} \mathrm{C}$ overnight. Cells were added with various concentration of the nano-ASLE for $24 \mathrm{hr}$. Then, the media were removed. Next, it was added with $100 \mu \mathrm{L}$ of DMEM and $10 \mu \mathrm{L}$ of MT'T solution to each well and incubated for $4 \mathrm{hr}$. Control cells received only the media. SDS-stopper $\mathrm{HCl} 0.1 \mathrm{~N}$ were added to evaluated formazan crystal. Moreover, ELISA reader was used to measure the absorbance in $595 \mathrm{~nm}$.

\section{Immunocytochemistry Staining}

HeLa cells were cultivated at a density of $2 \times 10^{5}$ cells/well in 24-well plates and incubated at $37^{\circ} \mathrm{C}$ overnight. The cells were treated with nano-ASLE 344.48, 688.96, $1377.92 \mu \mathrm{g} / \mathrm{mL}$ for overnight. The cells were layered with poly-L-lysine slides, then fixed using methanol for 3 min, permeabilized for 3 min, blocked in $2 \%$ BSA for hour. Monoclonal antibody caspase-3 was added for hour, then washed with PBS and added secondary antibody biotinylated universal for hour. The cells were incubated with HRP-streptavidin for $10 \mathrm{~min}$, then added $\mathrm{DAB}$ for $5 \mathrm{~min}$, washed again with aquadest, then counterstained with hematoxylin for $20 \mathrm{sec}$.

\section{Statistical Analysis}

This project was analyzed by using SPSS 21 (SPSS Inc., Chicago, IL), employing one-way analysis of variant (ANOVA) $(p<0.05)$, followed by Tukey HSD. Tabulated data were presented as the mean \pm standard deviation.

\section{RESULTS}

\section{Particle Size Analysis of Nano-ASLE}

The average particle size of nano-ASLE are obtained at $535.1 \mathrm{~nm}$ (Figure 1).

\section{Scanning Electron Microscope (SEM) of Nano- ASLE}

The SEM micrograph reveals the rough surface morphology, solid dense cubical and little bit aggregation (Figure 2). The spheres have diameters about $300 \mathrm{~nm}$. 


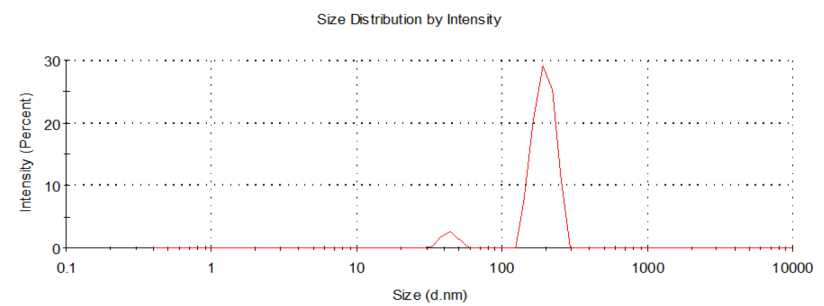

Figure 1: Particle size distribution by intensity of the nano-ASLE.

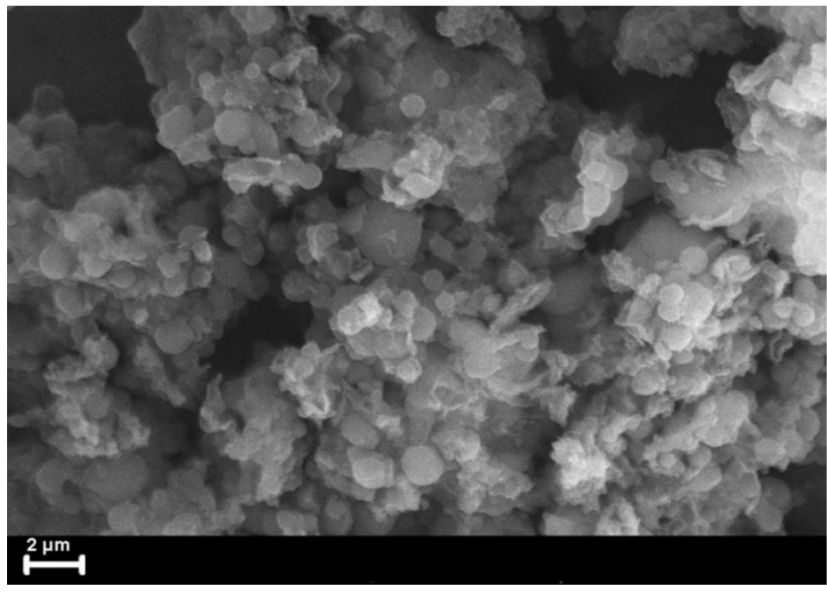

Figure 2: Scanning electron microscopic (SEM) of the nano-ASLE.

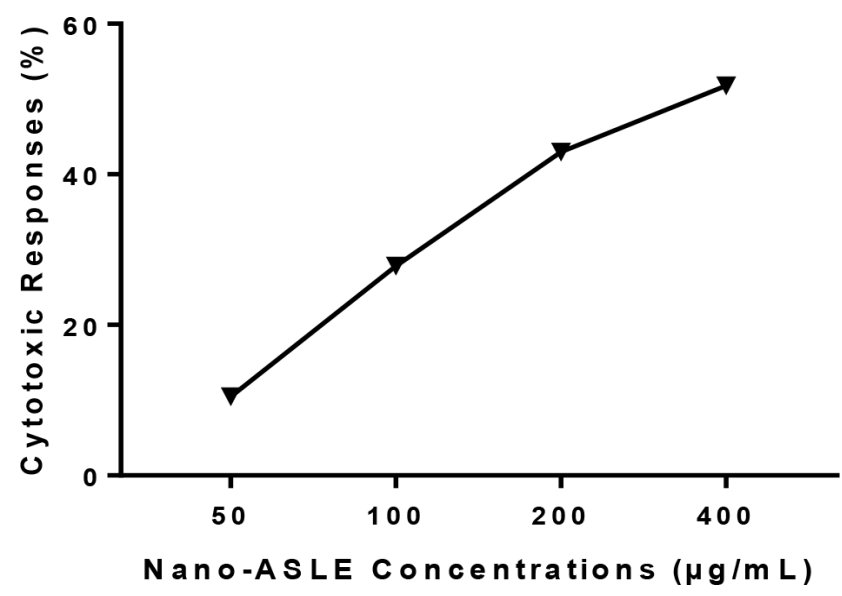

Figure 3: Cytotoxic responses of the nano-ASLE on HeLa cells.

\section{IC $_{50}$ Value of Nano-ASLE on HeLa Cells}

The highest reduction of HeLa cells is $48.25 \mu \mathrm{g} / \mathrm{mL}$ at dose of $400 \mu \mathrm{g} / \mathrm{mL}$. Meanwhile, the lowest reduction is $8.47 \mu \mathrm{g} / \mathrm{mL}$ at tose of $50 \mu \mathrm{g} / \mathrm{mL}$. The reductions of cell growth from the two other concentrations, $100 \mu \mathrm{g} / \mathrm{mL}$ and $200 \mu \mathrm{g} / \mathrm{mL}$ are $17.8 \mu \mathrm{g} / \mathrm{mL}$ and $22.96 \mu \mathrm{g} / \mathrm{mL}$, respectively. This study shows that the $\mathrm{IC}_{50}$ value of the nano-ASLE on HeLa cells is $344.48 \mu \mathrm{g} / \mathrm{mL}$. The result of cytotoxic responses of the nano-ASLE on HeLa cells is presented in Figure 3.
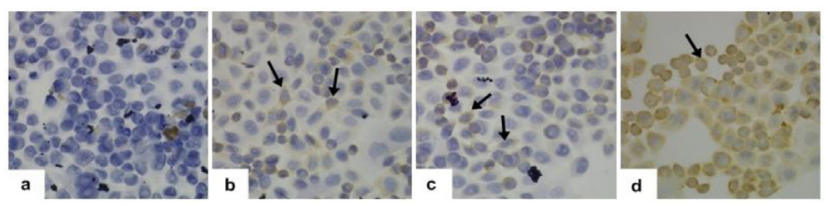

B

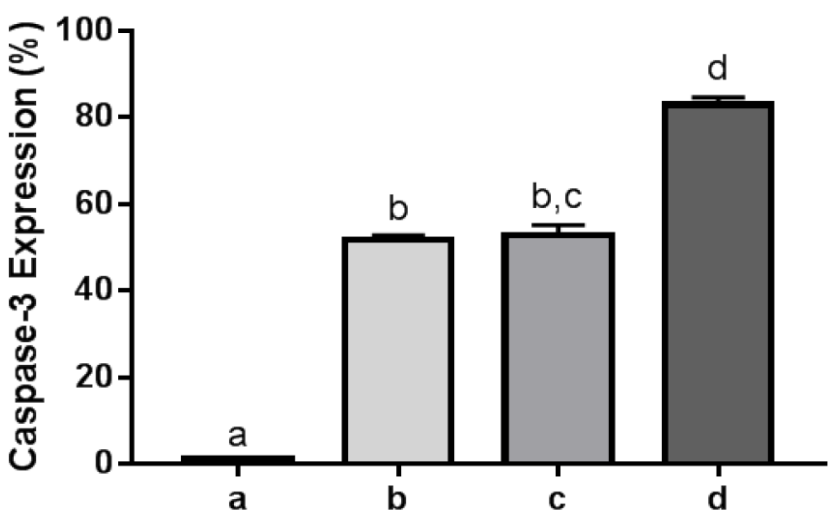

Figure 4: Effect of the nano-ASLE on caspase-3 on HeLa cell lines (400x).

The untreated group (a), caspase-3 expression (black arrow) shows in brown color in cytoplasm of nuclei of the group treated $344.48 \mu \mathrm{g} / \mathrm{mL}$ (b), $688.96 \mu \mathrm{g} / \mathrm{mL}$ (c), $1377.92 \mu \mathrm{g} / \mathrm{mL}$ (d); B: The bars represent the mean $\pm \mathrm{SD}$ of caspase- 3 expression scores treated with nano-ASLE on HeLa cells. The data is the mean $(n=4)$ with ${ }^{*} p$ value $\leq 0.05$ when compared to $\mathrm{IC}_{50}$ value significantly reduce the HeLa cells.

\section{Nano-ASLE Induced Caspase-3 Expression on HeLa Cells}

The result shows a rapid enhancement of caspase- 3 activity after treatment for $24 \mathrm{hr}$ (see Figure 4). The highest expression is found at the concentration of $1377.92 \mu \mathrm{g} / \mathrm{mL}$ (d) and has the mean score of 65.3 cell expression and the lowest score shows at the concentration of $344.48 \mu \mathrm{g} / \mathrm{mL}$ (b) and has the mean score of 45.3 cell expression. While, the concentration of $688.96 \mu \mathrm{g} / \mathrm{mL}$ (c) shows the mean of 57.4 cell expression. Furthermore, in control media (a), there are some little bit expression mean score of 1.2 cell expression.

\section{DISCUSSION}

In this study, the cytotoxic effect of the nano-ASLE against HeLa cells is investigated. Moreover, it reveals that the nano-ASLE has $\mathrm{IC}_{50}$ value of $344.48 \mu \mathrm{g} / \mathrm{mL}$. Releasing the bioactive compound with nanoparticles actually give alternative therapeutic ways dropping the drug to specific target and decrease the toxicity effects. Chitosan-coating can increase physicochemical stability, controlled release, improvement of cells interaction and of cells interaction and bioavailability of drugs and its efficacy. $^{13}$

Annona squamosa showed anticancer properties against several cancer cells in evaluation in vitro. In this study we 
suggests that it may be caused by the acetogenin effect that can inhibit the proliferation of cancer cells. Acetogenins selectivity indicated higher NADH oxidase activitites and the ATP demand due to their uncontrolled growth. ${ }^{14}$ The prior studies confirmed that the main compounds of annonaceous acetogenins are bullatacin and 12,15-cis-squamostatin-A. Another acetogenin is annonacin. It is a mono-tetrahydrofuran acetogenin isolated from Annonaceae family. The past studies showed that annonacin has cytotoxic effect and induces cell death with apoptosis through caspase- 3 related to the pathway to T24 bladder of cancer cells. ${ }^{15,16}$

The physiological form of cell death is induced by a variation of stimuli and several genes have been implicated in the apoptotic cell. Apoptosis is normal physiological process to eliminate the uncontrolled growth of that generate the cell destruction and homeostasis maintenance in healthy tissue. Apoptosis is also characterized by the plasma membrane bleeding, cell shrinkage, increasing cell density, chromatin condensation, karyorrhexis and the formation of apoptotic bodies. One of the apoptosis marker in the early stage is showed by caspase-3 expression. ${ }^{17,18}$ In this study, other compounds of Annona squamosa like flavonoid, alkaloid and saponin triggered ROS production that induced apoptosis through actions at different signal transduction pathways such as cyclin-dependent kinases (CDKs), caspases, Bcl-2 family members, epidermal growth factor (EGF)/epidermal growth factor receptor (EGFR), phosphatidylinositol-3-kinase/Akt, MAPK and NF- $\kappa \mathrm{B}$, which may affect cellular function by modulating genes or phosphorylating proteins. ${ }^{19}$ The result of caspase- 3 expression in immunocytochemistry shows that the increasing doses followed by the increasing amount of caspase- 3 expression.

Caspase- 3 produces an inactive zymogen, which is a $32 \mathrm{KDa}$ pro-caspase located in the cytoplasm that proteolytically cut at an aspartate residue to generate the cleaved fragments in the terminal and creates 12 $\mathrm{KDa}$ and $17 \mathrm{KDa}$ subunit. Two subunits are combined to activate caspase- 3 enzyme. This active caspase- 3 has a wide gap of activity over the cellular substrates in which it cleaves the cell substrates like DNA repair enzyme and the structural proteins. It also may lead endonucleases and caspase activation which can cause the DNA fragmentation. Furthermore, it cannot be recovered back because of the inactive form of DNA repair enzyme and it can reach apoptosis. ${ }^{20}$

Mitochondria is another vital organelle in activation of intrinsic pathway of apoptosis. In the present study, we observed damage of mitochondrial membrane potential after the treatment. The pathway is activated by several of factors, including the cytotoxic drugs and oxidative stress. Family of $\mathrm{Bcl}-2$ protein is dominated pathway, which leads to release of cytochrome-c from the mitochondria. Next, it binds together with procaspase- 9 and apaf- 1 which contribute to make the formation of apoptosom and activation of caspase-9, at last procaspase-3 activation to caspase-3 then lead activation of apoptosis formation. It is consistent with the previous study which showed that annonacin from Annonaceae family induces the apoptotic cell death in a Caspase-3 related to the pathway on endometrial cancer cells. Annonacin may deregulate the cell cycle arrest checkpoint to allow a cancer cell to enter mitosis and undergo apoptosis through caspase-mediated DNA fragmentation and also decrease Bcl-2, which eventually reduce cell proliferation of HeLa cells. ${ }^{21,22}$ Future study could be analyzed to find the accurate the value of $\mathrm{IC}_{50}$ from the nanoparticles form of Annona squmosa leaf extract. Thus, it can be concluded that chitosan basednanoparticles of Annona squamosa are found to have anti-cancer activity against the HeLa cells.

\section{CONCLUSION}

The present study demonstrated that nano-ASLE can inhibit the proliferation of HeLa cells with the $\mathrm{IC}_{50}$ value of $344.48 \mu \mathrm{g} / \mathrm{mL}$ via the intracellular mitochondrial pathway on caspase- 3 expression. In addition, the further studies are needed to obtain the loading efficiency, release of drug concentration and in vivo study of nano-ASLE to suppress HeLa cells.

\section{ACKNOWLEDGEMENT}

This study was funded by PMDSU grant with the reference number 1341/UN3.14/LT/2018 from KEMENRISTEKDIKTI of Indonesia.

\section{CONFLICT OF INTERST}

The authors declare no conflict interests.

\section{ABBREVIATIONS}

Nano-ASLE: Annona squamosa leaf extract induced by chitosan nanoparticles.

\section{REFERENCES}

1. Blackadar CB. Historical review of the causes of cancer. World J Clin Oncol. 2016;7(1): 54-86.

2. Khazaei S, Ramachandran V, Abdul HR, Mohd EN, Etemad A, Moradipoor S, et al. Flower extract of Allium atroviolaceum triggered apoptosis, activated caspase-3 and down-regulated antiapoptotic Bcl-2 gene in HeLa cancer cell line. Biomed Pharmacother. 2017;89:1216-26. 
3. Fadholly A, Proboningrat A, Iskandar RPD, Rantam FA, Sudjarwo SA. In vitro anticancer activity Annona squamosa extract nanoparticle on WiDr cells. J Adv Pharm Technol Res. 2019;10(4):149-54.

4. Ansori ANM, Susilo RJK, Hayaza S, Winarni D, Husen, SA. Renoprotection by Garcinia mangostana L. Pericarp extract in streptozotocin-induced diabetic mice. Iraqi J Vet Sci. 2019;33(1):13-9.

5. Fadholly A, Ansori ANM, Jayanti S, Proboningrat A, Kusala MKJ, Putri N, et al. Cytotoxic effect of Allium cepa L. extract on human colon cancer (WiDr) cells: In vitro Study. Research J Pharm and Tech. 2019;12(7):3483-6.

6. Raj DS, Vennila JJ, Aiyavu C, Panneerselvam K. The hepatoprotective effect of alcoholic extract of Annona squamosa leaves on experimentally induced liver injury in swiss albino mice. Int J Integr Biol. 2009;5(3):182-6.

7. Hopp DC, Zeng L, Gu Z, McLaughliin JL. Squamotacin: An annonaceous acetogenin with cytotoxic selectivity for the human prostate tumor cell line (PC-3). J Nat Prod. 1996;59(2):97-9.

8. Rupprecht JK, Chang C, Cassady JM, McLaughlin JL, Mikolajczak KL, Weisleder D. Asimicin, a new cytotoxic and pesticidal acetogenin from the pawpaw, Asimina triloba (Annonaceae). Heterocycles. 1986;24(5):1197-201.

9. Ma C, Wang $Q$, Shi $\mathrm{Y}, \mathrm{Li} \mathrm{Y}$, Chen $\mathrm{Y}$, Chen J. Three new antitumor annonaceous acetogenins from the seeds of Annona squamosa. Nat Prod Res. 2017;31(18):2085-90.

10. Vivek R, Thangam R, Muthuchelian K, Gunasekaran P, Kaveri K, Kannan S. Green biosynthesis of silver nanoparticles from Annona squamosa leaf extract and its in vitro cytotoxic effect on MCF-7 cells. Process Biochem. 2012;47(12):2405-10.

11. Ding R, Xie F, Hu Y, Fu S, Wu J, Fan J, et al. Preparation of endostatinloaded chitosan nanoparticles and evaluation of the antitumor effect of such nanoparticles on the lewis lung cancer model. Drug Deliv. 2017;24(1):300-8.

12. Kumar N, Salar RK, Prasad M, Ranjan K. Synthesis, characterization and anticancer activity of vincristine loaded folic acid chitosan conjugated nanoparticles on NCL-H460 non-small cell lung cancer cell line. Egypt J Basic Appl Sci. 2018;5(1):87-99.
13. Ganesan P, Ko H, Kim I, Choi DK. Recent trends in the development of nanophytobioactive compounds and delivery systems for their possible role in reducing oxidative stress in Parkinson's disease models. Int $\mathrm{J}$ of Nanomed. 2015;10(1):6757-72.

14. Aslan KP, Tuncer $\mathrm{H}$, Cihangir UA, Espino PJ, Darici H, Onaran I, et al. MiR-29a suppresses spermatogenic cell apoptosis in the testicular ischemia reperfusion injury by targeting TRPV4 channels. Int J Exp Pathol. 2017;96(5):294-300.

15. McLaughling JL. Paw paw and cancer: Annonaceous acetogenins from discovery to commercial products. J Nat Prod. 2008;71(7):1311-21.

16. Yuan SS, Chang HL, Chen HW, Yeh YT, Kao YH, Lin KH, et al. Annonacin, a mono-tetrahydrofuran acetogenin, arrests cancer cells at the $\mathrm{G} 1$ phase and causes cytotoxicity in a Bax- and caspase-3-related pathway. Life Sci. 2003;72(25):2853-61.

17. Ali MR, Yong MJ, Gyawali R, MosaddikA, Ryu YC, Cho SK. Mango (Mangifera indica L.) peel extracts inhibit proliferation of HeLa human cervical carcinoma cell via induction of apoptosis. J Korean Soc Appl Biol Chem. 2012;55(3):397405.

18. Günther A, Luczak V, Abel T, Baumann A. Caspase-3 and GFAP as early markers for apoptosis and astrogliosis in shRNA-induced hippocampal cytotoxicity. J Exp Biol. 2017;220(8):1400-4.

19. Sun L, Zhou W, Zhang H, Guo Q, Yang W, Li B, et al. Modulation of multiple signaling pathways of the plant-derived natural products in cancer. Front Oncol. 2019;9:1153.

20. Pfeffer CM, Singh ATK. Apoptosis: A target for anticancer therapy. Int $\mathrm{J}$ Mol Sci. 2018;19(2):448-58.

21. Ko Y, Wu T, Wu Y, Chang F, Guh J, Chung L. Annonacin induces cell cycledependent growth arrest and apoptosis in estrogen receptor-a-related pathways in MCF-7 cells. J Ethnopharmacology. 2011;137(3):1283-90.

22. Yap CV, Subramaniam KS, Khor SW, Chung I. Annonacin exerts antitumor activity through induction of apoptosis and extracellular signal-regulated kinase inhibition. Pharmacognosy Res. 2017;9(4):378-83.

\section{PICTORIAL ABSTRACT}

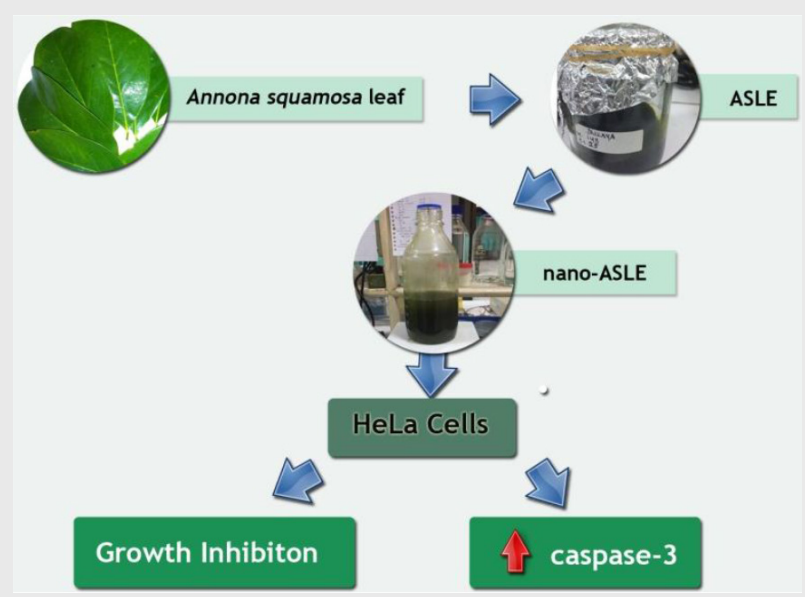

\section{SUMMARY}

Annona squamosa is called as Srikaya which belongs to Annonaceae family and considered as the medicinal plant. In this study nanoparticles of Annona squamosa leaf extract was designed to surpress the growth of HeLa cells and evaluate caspase- 3 expression as one of apoptosis marker of cells. Chitosan was used as nanoparticle substance to preserve releasing of the bioactive compound. The result of the work are nano-ASLE can surpress the growth of HeLa cell and induce caspase- 3 as a apoptosis marker.

\section{About Authors}

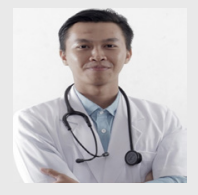

Amaq Fadholly, drh., M.Si. is a Ph.D candidate in Veterinary Science at Universitas Airlangga, Indonesia. His research area focuses on the natural products for cancer, pharmacology and veterinary reproduction.

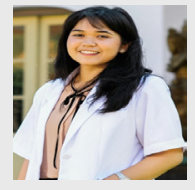

Regina Purnama Dewi Iskandar, drg., M.Imun. is a Ph.D candidate in Medical Science at Universitas Airlangga, Indonesia. Her research area focuses on genetic and proteomic aspects of craniofacial biology. 


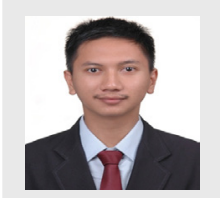

Arif Nur Muhammad Ansori, S.Si., M.Si. is a Ph.D candidate in Veterinary Science at Universitas Airlangga, Indonesia. His research area focuses on the natural products for cancer and antiviral agents.

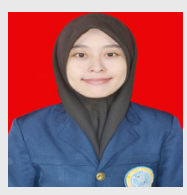

Annise Proboningrat, drh., M.Si. is a Ph.D candidate in Veterinary Science at Universitas Airlangga, Indonesia. Her research area focuses on the natural products for cancer.

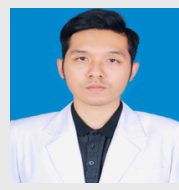

Alexander Patera Nugraha, drg., M.Imun. is a Ph.D candidate in Medical Science at Universitas Airlangga, Surabaya, Indonesia. His research area focuses on the bone biology, dental mesenchymal stem cell, orthodontics.

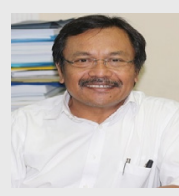

Prof. Dr. Fedik Abdul Rantam, drh. is a lecturer at Department of Veterinary Microbiology, Faculty of Veterinary Medicine, Universitas Airlangga. His research area focuses on stem cell and virology.

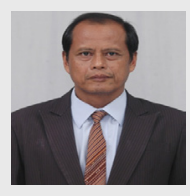

Prof. Sri Agus Sudjarwo, drh., Ph.D. is a lecturer at the Department of Pharmacology, Faculty of Veterinary Medicine,Universitas Airlangga. He graduated in Doctoral Degree at the Department of Pharmacology, Faculty of Agriculture, Tokyo University, Japan. His research focused on Pharmacology and Toxicology.

Cite this article: Fadholly A, Ansori ANM, Proboningrat A, Nugraha AP, Iskandar RPD, Rantam FA, et al. Apoptosis of HeLa Cells via Caspase-3 Expression Induced by Chitosan-Based Nanoparticles of Annona squamosa Leaf Extract: In vitro Study. Indian J of Pharmaceutical Education and Research. 2020;54(2):416-21. 